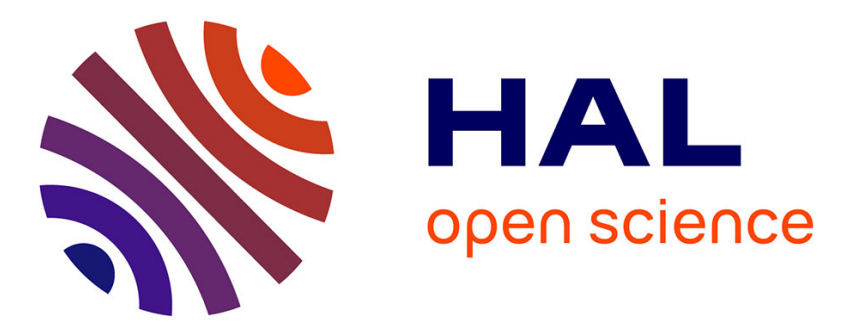

\title{
First evidence of a whale bone industry in the western European Upper Paleolithic: Magdalenian artifacts from Isturitz (Pyrénées-Atlantiques, France)
}

\author{
Jean-Marc Pétillon
}

\section{- To cite this version: \\ Jean-Marc Pétillon. First evidence of a whale bone industry in the western European Upper Pale- olithic: Magdalenian artifacts from Isturitz (Pyrénées-Atlantiques, France). Journal of Human Evo- lution, 2008, 54 (5), pp.720-726. 10.1016/j.jhevol.2007.12.006 . halshs-00391832}

\section{HAL Id: halshs-00391832 \\ https://shs.hal.science/halshs-00391832}

Submitted on 4 Jun 2009

HAL is a multi-disciplinary open access archive for the deposit and dissemination of scientific research documents, whether they are published or not. The documents may come from teaching and research institutions in France or abroad, or from public or private research centers.
L'archive ouverte pluridisciplinaire HAL, est destinée au dépôt et à la diffusion de documents scientifiques de niveau recherche, publiés ou non, émanant des établissements d'enseignement et de recherche français ou étrangers, des laboratoires publics ou privés. 
Please cite as: PÉTILLON J.-M. (2008) - First evidence of a whale-bone industry in the western European Upper Paleolithic: Magdalenian artifacts from Isturitz (Pyrénées-Atlantiques, France). Journal of Human Evolution, 54 (5): 720-726. doi:10.1016/j.jhevol.2007.12.006

\section{First evidence of a whale bone industry in the western European Upper Paleolithic: Magdalenian artifacts from Isturitz (Pyrénées-Atlantiques, France)}

Jean-Marc Pétillon

Laboratoire Archéologies et sciences de l'Antiquité, département d'ethnologie préhistorique Maison René Ginouvès, boîte 22, 21 allée de l'Université, F-92023 Nanterre

Email: jean-marc.petillon@mae.u-paris10.fr

Keywords: Upper Paleolithic, Magdalenian, osseous technology, marine resources, whale bone, Isturitz.

The economy of the hunter-gatherers from the Upper Paleolithic (UP) of western Europe is generally thought to have been based on the exploitation of land game. These animals were the main source of food and a major source of raw materials (e.g., Binford, 1968; Gamble, 1986). Marine and seashore resources, by contrast, appear to have had little or no importance in subsistence. As stressed by several authors (Poplin, 1983; Cleyet-Merle and Madelaine, 1995; Erlandson, 2001; Serangeli, 2003), this biased view of UP groups as "inland hunters" is first and foremost due to the Flandrian rise in sea level: the UP sites most likely to attest to the economic importance of the seashore are now under sea level. Some evidence found at inland sites - marine shells and depictions and faunal remains of marine fish, seals, auks, and cetaceans - do show that the seashore was regularly visited at that time (Serangeli, 2003). However, these remains are probably, almost in the literal sense, only the tip of a now submerged iceberg.

The underrepresentation of marine resources is particularly striking when one considers the industry made of hard animal materials. While perforated marine shells represent a significant part of UP personal ornaments (Taborin, 1993), other occurrences of worked items of marine origin are blatantly rare. According to Sonneville-Bordes and Laurent (1983), Poplin (1983), Cleyet-Merle and Madelaine (1995), and Serangeli (2003), the worked artifacts from the UP sites of western Europe (Mesolithic excluded) comprise only five items of marine origin, all from a Magdalenian context: one perforated seal tooth at Las Palmas (Cleyet-Merle and Madelaine, 1995), two at Isturitz (Passemard, 1924: Plate VI, 1944: Plate XXII), one at La Marche, and one carved sperm whale tooth at Le Mas d'Azil (Poplin, 1983). From the published data, it thus seems that shells were the only marine resource regularly exploited for industry (for ornaments, specifically) during the western European UP. 
Recent reexamination of osseous material from the Magdalenian layers of the Isturitz cave (Pyrénées-Atlantiques, France) has shown this idea to be erroneous. Several artifacts have now been identified deriving from cetacean bone, most probably whale bone. As will be developed below, these artifacts demonstrate the existence of technical exploitation of whale bone, proving that the seashore was also a place where Paleolithic people gathered specific materials for producing weapons and tools.

\section{The archaeological setting}

The Isturitz cave is located at the northwestern end of the Pyrénées Mountains, $150 \mathrm{~m}$ above present sea level (Fig. 1). The two main chambers of the cave, the Grande salle and the Salle de Saint-Martin, yielded incredibly rich UP deposits that were excavated during the early and middle twentieth century (Passemard, 1924, 1944; Saint-Périer, 1930, 1936; Saint-Périer and Saint-Périer, 1952). Most of the archaeological material is curated in the Musée d'Archéologie Nationale (MAN, Yvelines, France). In the Grande salle, the excavators distinguished two Magdalenian layers, I/F1 (top) and II/E (bottom), corresponding respectively to the Upper and Middle Magdalenian phases (stratigraphic review in Pétillon, 2004a). In the Salle de SaintMartin, only one Magdalenian layer, SI/E $\omega$, was identified and attributed to the Middle Magdalenian.

\section{Identification of the artifacts}

During previous research focused on the antler industry of layer I/F1 (Pétillon, 2004b, 2006), I noted several osseous artifacts with unusual characteristics, described below. Having never met this material before, and misled by the fact that several of the artifacts had been published among antler tools (see Figure 38/3 and Plates III/5/10/11 and IV/27 in Saint-Périer, 1930; see Figure 56 in Passemard, 1944), I mentioned them briefly as possibly being made of "antler of unusual structure" (Pétillon, 2004b: 112; 2006: 78). At the end of 2006, unsatisfied with this default attribution, I systematically searched for similar objects in the Isturitz Magdalenian material at MAN and came up with about 60 worked osseous rods, most of them fragmentary, coming from the three layers I/F1, II/E, and SI/E $\omega$. This larger sample and a more thorough search for comparable published material led to the hypothesis that the artifacts were made of the bones of sea mammals.

All of the artifacts were shown to Dr. F. Poplin from the Muséum National d'Histoire Naturelle, who gave an expert confirmation for the attribution of 57 specimens as cetacean bone, most probably whale bone (Table 1). Confirmative statements and a wealth of information also came from Drs. R. Campbell-Malone, M. Christensen, and A.V. Margaris.

\section{Raw material}

Antler and land-mammal bone are the two main materials used in UP osseous industry (Albrecht, 1977). Both are composed of compact and cancellous tissues, the transition from one tissue to the other being abrupt and easy to distinguish with the naked eye (Fig. 2a,b). The artifacts considered here present no such clear distinction. Their section shows a structure intermediate between that of compact and cancellous bone: compact bone enclosing relatively sparse trabeculae (Fig. 2c-h). The structure of the material is homogeneous: with few exceptions 
(Fig. 2f), the trabeculae are rather evenly distributed and they never indicate a "spongy" side or end opposed to a "compact" one; they can be seen on all sides of the objects and across their entire length (Fig. 3). These features are never present on other osseous materials such as antler, bones of large and small land mammals, or ivory. But they are identical to those of artifacts made from cetacean bone represented in American collections (for a recent review and identification criteria, see Margaris, 2006). Indeed, the distinctive characteristics of cetacean bones are that they generally have no medullary cavity and, although surrounded by a cortical shell, are mostly composed of cancellous tissue (Felts and Spurrell, 1965; Buffrénil and Schoevaert, 1988; Campbell-Malone, 2007). This structure is interpreted as a specific adaptation to buoyancy in deep water (Taylor, 2000; Ricqlès and Buffrénil, 2001; Gray et al., 2007). On whole bones of cetaceans, the density of the cancellous tissue is variable, ranging from a very porous structure to a much denser tissue (see Fig. 18 in Felts and Spurrell, 1965). The Magdalenian specimens show that the denser parts were preferred for artifact manufacture.

The original size of the osseous core is difficult to determine because almost all of the artifacts are fragmentary. However, despite this intense fragmentation, twelve of them $(21.1 \%)$ are still more than $120 \mathrm{~mm}$ long. The longest specimen measures $250 \mathrm{~mm}$ and has an almost straight profile; it is broken at one end, but the fracture apparently did not occur near the original end of the object (the specimen is $12 \mathrm{~mm}$ wide and thick at the level of the fracture), which means it must have originally been much longer. For the whole sample, width and thickness average 11.9 and $10.2 \mathrm{~mm}$, respectively. Given these dimensions, it is most likely that the bones derive from large cetaceans (i.e. whales), as opposed to smaller species (dolphin, propoise).

The trabeculae have a longitudinal orientation that is, in most cases, in line with the longitudinal axis of the artifact (Fig. 3). This orientation and the fact that all of the objects have a straight profile suggest that the bone came from the skeletal elements with an elongated shape, such as mandible, vertebral process, rib, radius, or ulna. It is not possible to be more specific because of the objects' high fragmentation and level of transformation.

\section{Typology and stratigraphic distribution}

Fragments of projectile points are the most numerous ( 25 specimens), and all come from Middle Magdalenian layers (Table 2; Table 3; Fig. 4a,b). The nine proximal fragments all display a simple, blunt base, which suggests hafting by insertion into a socket at the distal end of a projectile shaft (e.g., see Figure 3.11 in Knecht, 1993). One broken point fragment was perforated and recycled as a pendant (Fig. $4 \mathrm{~g})$.

The 17 foreshafts form the second best-represented category (Fig. 4c,d). Each of the two

nearly complete specimens has opposite double-beveled and forked ends. Morphometric study and experimental replication of similar antler foreshafts show that the beveled end was hafted to the projectile shaft, while the forked end was interlocked with the forked base of a projectile point (Pétillon and Cattelain, 2004; Pétillon, 2006). By analogy, 15 fragments could be classified as either proximal or distal foreshaft fragments.

The stratigraphic distribution of the foreshafts is a complex matter. Almost all specimens from the Saint-Périer excavations (four of five) are from the Upper Magdalenian layer I/F1, while the majority of the specimens in the Passemard collection (nine of twelve) are from the Middle Magdalenian layer II/E. Although a detailed discussion is beyond the scope of this paper, a 
comprehensive analysis of the stratigraphic distribution of the Magdalenian artifacts shows that this situation is probably due to an excavation mistake by Passemard: he apparently included part of the Upper Magdalenian material in the Middle Magdalenian layer (Pétillon, 2004a). It is therefore plausible that all foreshafts actually stem from the Upper Magdalenian.

Three other artifacts from layer I/F1 and two from layer SI/E $\omega$ show traces of use as wedges (Fig. 4f): compression and blunting of the working edge, opposite to a striking platform with signs of percussion (crushing and chipping). Morphometric and technological evidence suggest that these wedges are not the result of a specific production sequence, but rather recyclings of foreshaft and point fragments selected for their large dimensions (Table 3).

Finally, two fragments from layer II/E fit into the morphometric range of "half-round rods" (Fig. 4e). These implements present a particular cross section, with a flat side opposite a convex one, and were probably mounted in pairs to form a "bivalve" object with a biconvex cross section (Feruglio and Buisson, 1999; Rigaud, 2006).

This typological survey shows that the large majority of the Isturitz whale-bone artifacts are related to hunting technology, especially projectile elements (points and foreshafts). The second point is that, at Isturitz, all types of whale-bone artifacts have numerous equivalents made of reindeer antler, showing similar ty pology and stratigraphic distribution (see inventory in Mujika, 1991).

\section{Discussion}

These artifacts reveal that the Magdalenians from Isturitz regularly exploited bone material of marine origin in their osseous industry, a technical trait previously unknown for the western European UP. The artifacts also represent the first non-ornamental use of a marine resource to be documented in UP groups. As stated above, this discovery sheds new light on the economic relationship of the Magdalenians with the now submerged seashore. However, it is not necessary to posit the existence of whaling techniques during the Magdalenian, since whale strandings would have provided an abundant material (Cleyet-Merle and Madelaine, 1995).

The Isturitz cave lies east of the present Atlantic seashore, at a $40 \mathrm{~km}$ trip distance when following the easiest travel path along the valleys (Fig. 1). During the Middle and Upper Magdalenian (ca. 16,500-12,000 calBC), the sea level was between 100 and $80 \mathrm{~m}$ lower, but on this part of the coast, the seashore was likely not more than $10-15 \mathrm{~km}$ west of its present position (Thibault, 1979). During Magdalenian times, the nearest possible source of whale bone would therefore have been $50-60 \mathrm{~km}$ from the cave. This is not especially far compared to the long-distance procurement of some flint types (Simonnet, 1996) or the wide diffusion of marine shells into the interior parts of western Europe (Taborin, 1993).

The number of artifacts made from whale bone is small compared to the hundreds of typologically similar antler items from the same layers. However, the important point is that, although rare, the artifacts made using whale bone are present in the entire Magdalenian sequence of the cave. These artifacts thus represent an industry in the whole sense of the term-that is, a technical tradition consistent through time and involving specific knowledge.

Two questions concerning this industry remain to be addressed and can only be briefly brought up here. The first one is to determine the reasons why the Magdalenians chose this raw material to manufacture a portion of their projectile points, foreshafts, and wedges. If, as a first 
approach, we consider only the intrinsic properties of the material-ignoring extrinsic factors such as economic availability, symbolic status, etc.-it appears that its large dimensions

probably played a role: compared to antlers or to the bones of most land mammals, whale bones allow the manufacture of larger tools (Betts, 2007). The peculiar mechanical properties of whale bone must also be considered. Preliminary experimental results indicate that, compared to land mammal bones, whale bones are more resilient and thus more suitable for the manufacture of items subject to impacts (Scheinsohn and Ferretti, 1995). For a detailed discussion, we refer the reader to the work of Margaris (2006), who analyzed Alutiiq assemblages in which whale bone was used to make comparable types of implements (projectile tips and woodworking wedges). As Margaris (2006) argued, further research on this topic should include extensive experimental replication and mechanical testing, as conducted on whale mandibular cortical and trabecular bone tissue in another study (Campbell-Malone, 2007).

The second important question is to assess the extent of this technical tradition in time and space: are there whale-bone artifacts outside Isturitz? Do they exist before the Magdalenian? The identification of the Isturitz items more than 70 years after their recovery shows that, if similar artifacts exist in other collections, they are likely to have been misclassified as made of bone/antler from land mammals. One of the purposes of this paper is to bring to the attention of specialists in European Paleolithic osseous tools the possible occurrence of this unusual raw material.

\section{Acknowledgements}

I thank François Poplin for providing his diagnosis on the artifacts. Thanks also to Catherine Schwab, curator of the Palaeolithic Department of MAN, and her assistant, MarieSylvie Larguèze, for help with the collections. Sincere thanks are extended to Regina CampbellMalone, Marianne Christensen, Dominique Legoupil, Claire Letourneux, Amy Margaris, and Christian Normand for thought-provoking discussions and suggestions. This paper was greatly improved by the comments of the editor and three anonymous reviewers. This work was supported by a research grant from the Ile-de-France Regional Council.

\section{References}

Albrecht, G., 1977. Testing of materials as used for bone points in the Upper Palaeolithic. In: Camps-Fabrer, H. (Ed.), Méthodologie Appliquée à l'Industrie de l'Os Préhistorique. CNRS, Paris, pp. 119-124.

Betts, M.W., 2007. The Mackenzie Inuit whale bone industry: raw material, tool manufacture, scheduling, and trade. Arctic 60, 129-144.

Binford, L.R., 1968. Post-Pleistocene adaptations. In: Binford, S.R., Binford, L.R. (Eds.), New Perspectives in Archeology. Chicago, Aldine, pp. 313-341.

Buffrénil, V. de, Schoevaert, D., 1988. On how the periosteal bone of the delphinid humerus becomes cancellous: ontogeny of a histological specialization. J. Morphol. 198, 149-64.

Campbell-Malone, R., 2007. Biomechanics of North Atlantic Right Whale: mandibular fracture as a fatal endpoint for blunt vessel-whale collision modeling. Doctoral thesis in biological 
oceanography, Massachusetts Institute of Technology/Woods Hole Oceanographic Institution.

Cleyet-Merle, J.J., Madelaine, S., 1995. Inland evidence of human sea coast exploitation in Palaeolithic France. In: Fischer, A. (Ed.), Man and Sea in the Mesolithic: Coastal Settlement Above and Below Present Sea Level. Oxbow Books, Oxford, pp. 303-308.

Erlandson, J.M., 2001. The archaeology of aquatic adaptations: paradigms for a new millenium. Journal of Archaeological Research 9, 287-350.

Felts, W.J.L., Spurrell, F.A., 1965. Structural orientation and density in cetacean humeri. Am. J. Anat. 116, 171-203.

Feruglio, V., Buisson, D., 1999. Accolements de pièces à section demi-ronde. In: Julien, M., Averbouh, A., Ramseyer, D. (Eds.), Préhistoire d'Os, Recueil d'Etudes sur l'Industrie Osseuse Préhistorique Offert à Henriette Camps-Fabrer. Publications de l'Université de Provence, Aix-en-Provence, pp. 143-149.

Gamble, C., 1986. The Palaeolithic Settlement of Europe. Cambridge, Cambridge University Press.

Gray, N.M., Kainec, K., Madar, S., Tomko, L., Wolfe, S., 2007. Sink or swim? Bone density as a mechanism for buoyancy control in early Cetaceans. Anat. Rec. 290, 638-653.

Knecht, H., 1993. Early Upper Paleolithic approaches to bone and antler projectile technology. In: Peterkin, G.L., Bricker, H.M., Mellars, P. (Eds.), Hunting and Animal Exploitation in the Later Palaeolithic and Mesolithic of Eurasia. APAAA, Washington, DC, pp. 33-47.

Margaris, A.V., 2006. Alutiiq engineering: the mechanics and design of skeletal technologies in Alaska's Kodiak archipelago. Ph.D. Dissertation, University of Arizona.

Mujika Alustiza, J.A., 1991. La industria ósea del Paleolítico superior y Epipaleolítico del Pirineo occidental, Ph.D. Dissertation, Universidad de Deusto.

Passemard, E, 1924. Les Stations Paléolithiques du Pays Basque et leurs Relations avec les Terrasses d'Alluvions. Bodiou, Bayonne.

Passemard, E., 1944. La caverne d'Isturitz en Pays Basque. Préhistoire 9, 7-95.

Pétillon, J.M., 2004a. Lecture critique de la stratigraphie magdalénienne de la Grande Salle d'Isturitz (Pyrénées-Atlantiques). Antiquités Nationales 36, 105-131.

Pétillon, J.M., 2004b. Des Magdaléniens en armes. Technologie des armatures de projectiles en bois de cervidé du Magdalénien supérieur de la grotte d'Isturitz (Pyrénées-Atlantiques). Ph.D. Dissertation, Université de Paris I Panthéon Sorbonne.

Pétillon, J.M., 2006. Des Magdaléniens en Armes. Technologie des Armatures de Projectile en Bois de Cervidé du Magdalénien Supérieur de la Grotte d'Isturitz (Pyrénées-Atlantiques). CEDARC, Treignes.

Pétillon, J.M., Cattelain, P., 2004. Nouvel examen de l'armature composite magdalénienne du Tuc d'Audoubert (Montesquieu-Avantès, Ariège). Bull. Soc. préhist. Fr. 101 (1), 45-53.

Poplin, F., 1983. La dent de Cachalot sculptée du Mas d'Azil, avec remarques sur les autres restes de cétacés de la Préhistoire française. In: Poplin, F. (Ed.), La Faune et l'Homme Préhistoriques. Société préhistorique française, Paris, pp. 81-94.

Ricqlès, A. de, Buffrénil, V. de, 2001. Bone histology, heterochronies and the return of Tetrapods to life in water: where are we? In: Mazin, J.M., Buffrénil, V. de (Eds.), Secondary Adaptation of Tetrapods to Life in Water. Friedrich Pfeil Verlag, München, pp. 289-310. 
Rigaud, A., 2006. Etude technologique des baguettes demi-rondes de Labastide (HautesPyrénées). Archéologie des Pyrénées Occidentales et des Landes 25, 229-246.

Saint-Périer, R. de, 1930. La Grotte d'Isturitz, I: le Magdalénien de la Salle de Saint-Martin. Masson, Paris.

Saint-Périer, R. de, 1936. La Grotte d'Isturitz, II: le Magdalénien de la Grande Salle. Masson, Paris.

Saint-Périer, R. de, Saint-Périer, S. de, 1952. La Grotte d'Isturitz, III: les Solutréens, les Aurignaciens et les Moustériens. Masson, Paris.

Scheinsohn, V., Ferretti, J.L., 1995. The mechanical properties of bone materials in relation to the design and function of prehistoric tools from Tierra del Fuego, Argentina. J. Archaeol. Sci. 22, 711-717.

Serangeli, J., 2003. La zone côtière et son rôle dans les comportements alimentaires des chasseurs-cueilleurs du Paléolithique supérieur. In: Patou-Mathis, M., Bocherens, H. (Eds.), Le Rôle de l'Environnement dans les Comportements des Chasseurs-cueilleurs Préhistoriques. Archaeopress/BAR International Series 1105, Oxford, pp. 67-82.

Simonnet, R., 1996. Approvisionnement en silex au Paléolithique supérieur: déplacements et caractéristiques physionomiques des paysages, l'exemple des Pyrénées centrales. In: Delporte, H., Clottes, J. (Eds.), Pyrénées Préhistoriques: Arts et Sociétés. CTHS, Paris, pp. 117-128.

Sonneville-Bordes, D. de, Laurent, P., 1983. Le phoque à la fin des temps glaciaires. In: Poplin, F. (Ed.), La Faune et l'Homme Préhistoriques. Société préhistorique française, Paris, pp. 6980.

Taborin, Y., 1993. La Parure en Coquillage au Paléolithique. CNRS, Paris.

Taylor, M.A., 2000. Functional significance of bone ballast in the evolution of buoyancy control strategies by aquatic tetrapods. Historical Biol. 14, 15-31.

Thibault, C., 1979. L'évolution géologique de l'Aquitaine méridionale à la fin des temps glaciaires. In: Sonneville-Bordes, D. de (Ed.), La Fin des Temps Glaciaires en Europe: Chronostratigraphie et Ecologie des Cultures du Paléolithique Final. CNRS, Paris, pp. 143-150. 
Table 1. Number of whale-bone artifacts from the Isturitz Magdalenian layers in the Passemard and Saint-Périer collections at the MAN. Numbers in square brackets refer to specimens whose identification as whale bone is likely but not certain because of taphonomic problems (too fragmented, with concretions, altered surface, section not observable, etc.).

\begin{tabular}{|c|c|c|c|c|}
\hline \multirow{2}{*}{ Layer } & \multirow{2}{*}{ Chamber } & \multirow{2}{*}{$\begin{array}{l}\text { Magdalenian } \\
\text { phase }\end{array}$} & \multicolumn{2}{|c|}{ Number of specimens } \\
\hline & & & Passemard & Saint-Périer \\
\hline $\mathrm{I} / \mathrm{F} 1$ & Grande Salle & Upper & $4[+1]$ & $4[+1]$ \\
\hline $\mathrm{II} / \mathrm{E}$ & Grande Salle & Middle & $18[+5]$ & $8[+5]$ \\
\hline $\mathrm{SI} / \mathrm{E} \omega$ & $\begin{array}{lll}\begin{array}{l}\text { Salle } \\
\text { Martin }\end{array} & \text { de } & \text { St } \\
\end{array}$ & Middle & 1 & $8[+1]$ \\
\hline refitting I/F $1+$ II/E & Grande Salle & $?$ & 0 & 1 \\
\hline & \multicolumn{2}{|l|}{ TOTAL } & $23[+6]$ & $21[+7]$ \\
\hline
\end{tabular}

Table 2. Typological and stratigraphic distribution of the whale bone artifacts from the Isturitz Magdalenian layers.

\begin{tabular}{|c|c|c|c|c|c|}
\hline & \multirow[t]{2}{*}{$\mathrm{I} / \mathrm{F} 1$} & \multirow{2}{*}{\begin{tabular}{|l|}
$\mathrm{II} / \mathrm{E}$ \\
8 \\
\end{tabular}} & \multirow{2}{*}{$\begin{array}{l}\text { SI/E } \omega \\
1\end{array}$} & \multirow[t]{2}{*}{ refit. I/F $1+\mathrm{II} / \mathrm{E}$} \\
\hline \multirow{3}{*}{$\begin{array}{l}\text { projectile } \\
\text { points }\end{array}$} & proximal fragments & & & & \\
\hline & mesial fragments & & 7 & 5 & \\
\hline & distal fragments & & 3 & 1 & \\
\hline \multirow{3}{*}{ foreshafts } & complete & 2 & & & \\
\hline & proximal fragments & 1 & 7 & & \\
\hline & distal fragments & 4 & 3 & & \\
\hline \multirow{2}{*}{ wedges } & complete & 2 & & & \\
\hline & distal fragments & 1 & & 2 & \\
\hline \multicolumn{2}{|c|}{ half-round rods } & & 2 & & \\
\hline \multicolumn{2}{|c|}{ unidentified rod fragments } & & 6 & 1 & 1 \\
\hline \multicolumn{2}{|l|}{ TOTAL } & 10 & 36 & 10 & 1 \\
\hline
\end{tabular}

Table 3. Dimensions of the typologically identified whale bone artifacts from the Isturitz Magdalenian layers (in millimeters). Given the scarcity of complete specimens, the length of the longest fragments gives an order of magnitude for the original length of some of the objects. On projectile points, width and thickness are always maximal at the juncture between the base and the mesial part; thus, these values were plotted only for the nine fragments where this segment was preserved.

\begin{tabular}{|l|l|l|l|l|l|l|}
\cline { 2 - 6 } \multicolumn{1}{c|}{} & $\begin{array}{l}\text { Number } \\
\text { specimens }\end{array}$ & $\begin{array}{l}\text { Mean } \\
\text { width }\end{array}$ & $\begin{array}{l}\text { Mean } \\
\text { thickness }\end{array}$ & $\begin{array}{l}\text { Length of complete } \\
\text { specimens }\end{array}$ & $\begin{array}{l}\text { Length of the two } \\
\text { longest fragments }\end{array}$ \\
\hline projectile points & 25 & 0 & 13.5 & 11.3 & NA & $113.0 ; 138.9$ \\
\hline foreshafts & 15 & 2 & 11.6 & 10.5 & $171.0 ; 171.5$ & $182.5 ; 250.0$ \\
\hline wedges & 3 & 2 & 14.0 & 13.0 & $127.2 ; 161.0$ & $98.0 ; 128.6$ \\
\hline half-round rods & 2 & 0 & 13.2 & 6.3 & NA & $75.3 ; 109.0$ \\
\hline
\end{tabular}


Fig. 1. Map showing the location of the Isturitz cave between the Pyrénées Mountains and the Atlantic Ocean. The "-100 m" limit shows the location of the Paleolithic seashore ca. $100 \mathrm{~m}$ under present sea level.

Fig. 2. Cross-section views of an antler point fragment from Isturitz (a), a worked land-mammal rib fragment from Lespugue (b), and 6 whale-bone artifacts from Isturitz (c-h). On h, the dark triangular shape is sediment staining.

Fig. 3. Detail of the surface of 4 whale-bone artifacts, showing the orientation of the trabeculae. The trabeculae can be seen on all sides of the objects, and across their entire length. a: proximal fragment of projectile point with simple, blunt base (layer II/E); b: foreshaft proximal fragment (layer II/E); c: wedge (layer I/F1); d: fragment of unidentified object (layer SI/E $\omega$ ).

Fig. 4. Whale-bone artifact types from the Isturitz Magdalenian. a: projectile point mesial fragment (layer SI/E $\omega$ ); b: proximal fragment of projectile point with simple, blunt base (layer $\mathrm{SI} / \mathrm{E} \omega$ ); c: foreshaft (layer I/F1); d: foreshaft distal fragment (layer I/F1); e: half-round rod fragment (layer II/E); f: wedge (layer I/F1); g: mesial fragment of projectile point recycled as pendant (layer II/E). b: same artifact as Fig. 2c; c: same artifact as Fig. 2g. 


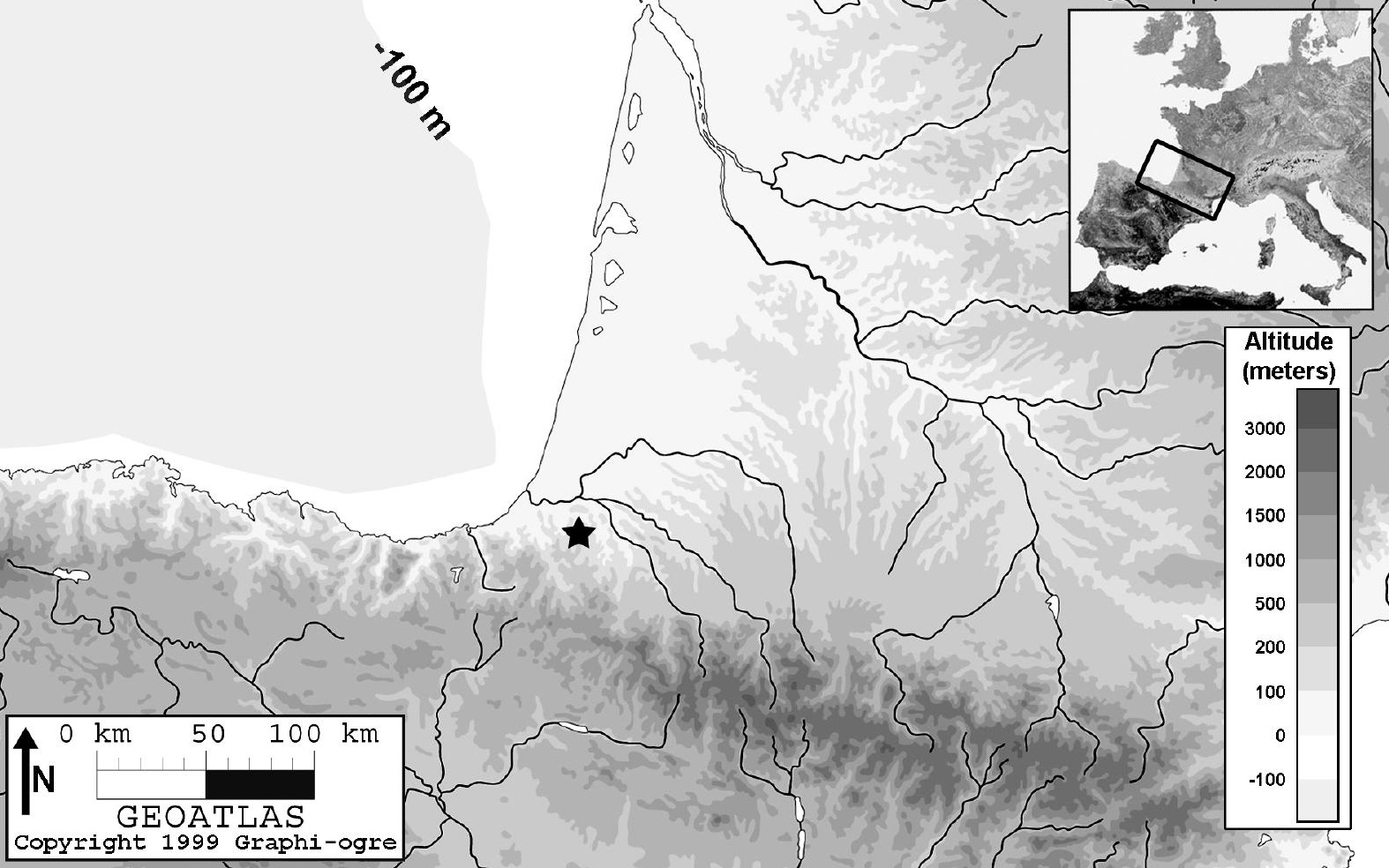



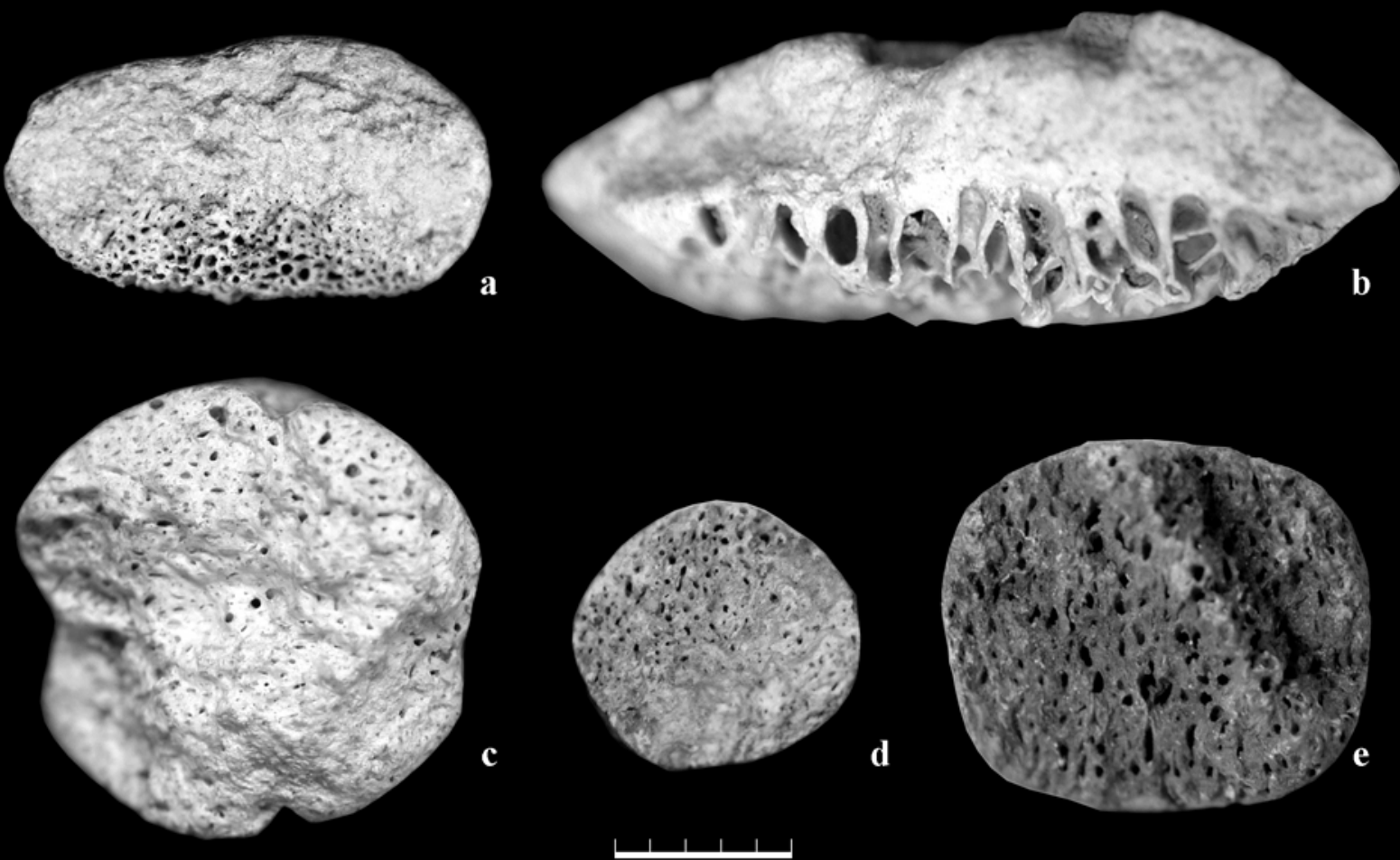

\section{$5 \mathrm{~mm}$}
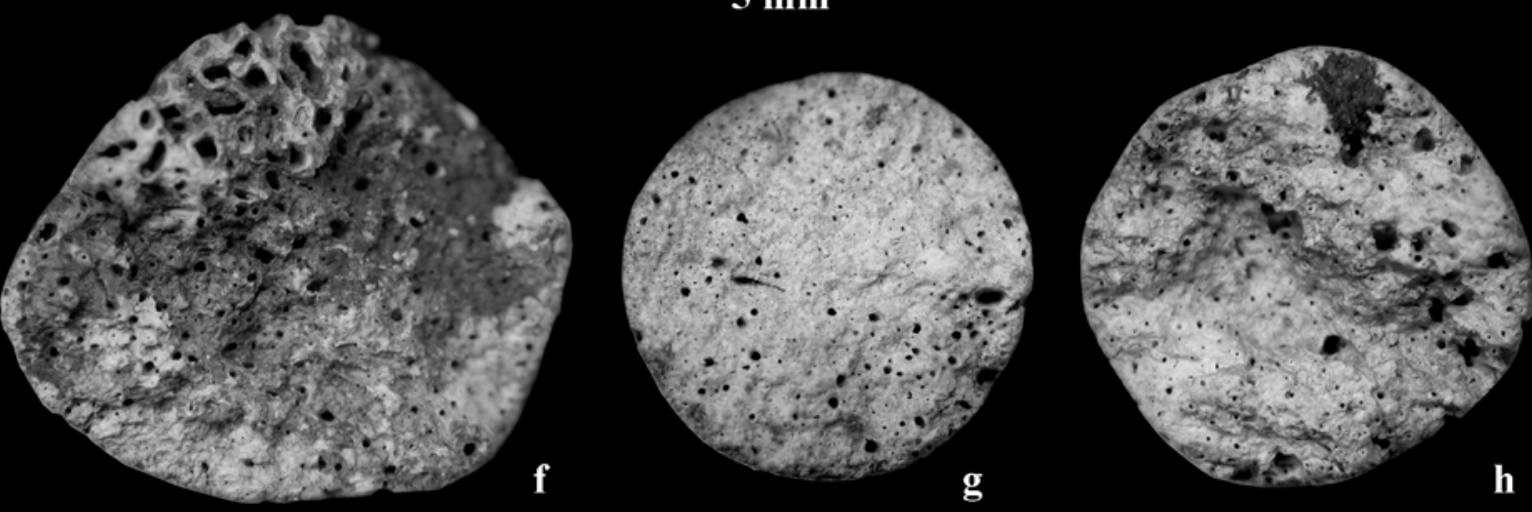


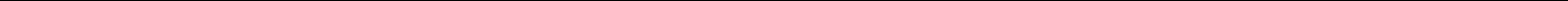




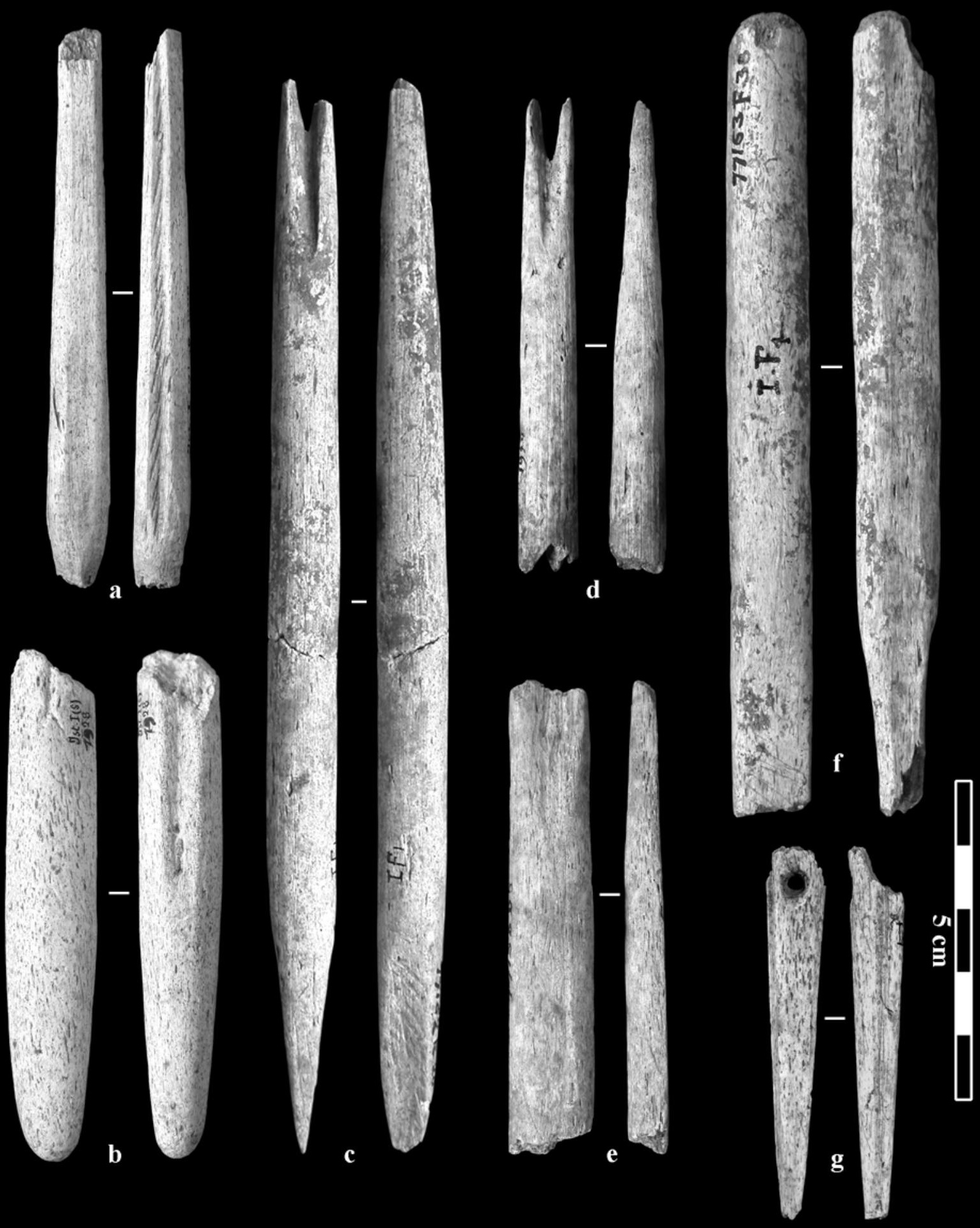

